\title{
GLOBALIZÁCIÓ ÉS A VILÁGVÁROSOK ÁLTAL URALT TÉR ${ }^{1}$ \\ (The Space Ruled by Globalisation and Metropolises) \\ ERDŐSI FERENC
}

Kulcsszavak:

világvárosok globális városok közlekedés infokommunikáció

A világvárosok mibenlétéröl, az azt meghatározó tényezók számáról és jelentôségéröl sokféle nézet alakult ki. A szerzö a korábbi képet ámyaltabbá teszi az intermetropolisz-közlekedés és infokonmunikációs forgalom elemzésével, valamint néhány ,puha" tényezö világvárosokhoz való viszonyának értékelésével.

\section{Bevezetés}

Ókori eredetủ, a - középkorban vár- és eródítményrendszerek kialakításában realizálódó - felismerés, hogy a területek feletti uralomhoz elegendó egyes stratégiai jelentőségú pontok birtoklása. Kérdés, hogy a pont/terület dichotomia milyen megközelítési módot preferál a terület- és városfejlesztés viszonyának kezeléséhez. Anélkül, hogy e rendkívül szétágazó és seregnyi kutató által vizsgált téma akárcsak nagyvonalú összefoglalását megtennénk, csupán azt a tényt emeljük ki, hogy az utóbbi időben a kölcsönkapcsolat egyik ágának hangsúlyt adva mind többen vallják, hogy a régiók fejlödésében a régióközpont városnak meghatározó szerepe van (mert az szolgált telephelyéül korunk fỏ fejlesztő erőinek, húzótényezóinek), következésképpen fejlesztésével kedvezően (és a leghatékonyabb módon) befolyásolható az egész régió állapota. E teória vitathatósága a vidéki, kis/közepes centrumvárosokkal rendelkezó régiók esetében nyilvánvaló, viszont az egészen más nagyságrendet képviselö világvárosok fölénye vonzáserö, valamint a szinte mindenre kiterjedó befolyásolás tekintetében az öket kedvezményező globalizáció elörehaladtával mind világosabban megmutatkozik.

A nagyvárosok kialakulása egy többtényezös - alapvetỏen spontán, városrendezési múveletekkel és szabályozással csak bizonyos mértékig befolyásolható - folyamat eredménye. Erős leegyszerúsítéssel a Harmadik Világ sokmilliós ,hólabda" település-konglomerátum gigantjai igazából a posztkoloniális társadalmak szociális összeomlásának kényszerképződményei: az urbanizáció „,fogyatékos" gyermekei, az éhhalállal fenyegetó nyomor elől bemenekülók áradata tartja fenn a még a 21. sz. elején is regisztrálható növekedésüket. A „civilizált" országokban viszont a települések korábbi növekedésében már közrejátszott az emberi tevékenységek városban tömörülése következtében létrejött gazdasági elönyök (az 1930/50-es évektỏl különösen az agglomerációs előnyök) felismerése.

A nagyvárosok és kiterjedt vonzáskörzetük közötti funkcionális kapcsolatok, a nagyvárosi térségek befolyásolása szempontjából másodlagos jelentőségü, vagy 
éppenséggel elhanyagolható körülmény, hogy az adott város fejlödésének éppen melyik fázisát éli meg, mert a dezurbanizációs fázisban az igazgatási határain belüli népességének csökkenése sem akadálya annak, hogy hatalmát nemcsak nagyobb területre terjessze ki, de erőteljesebben is gyakorolja. Mind világosabban kirajzolódik a nagyvárosok kettös „viselkedése”

- miközben lakókörnyezetként sokak (de nem mindenki) számára taszítóan hatnak és a szuburbiákba való kiköltözéssel, valamint a periurbanizációval népességet veszítenek (természetesen a már nem ritka reurbanizáció lassíthatja a lakosságszám apadását),

- a bennük összpontosuló, intenzifikálódó és intézményesülö, korunkban felértékelődő, vagy teljesen új hatalmi tényezőnek minősülő gazdasági/társadalmi tevékenységek/médiumok révén funkcionális kisugárzásukat növelni képesek.

Az előbbi megfontolásokból kiindulva tanulmányunkban arra keressük a választ, hogy a globalizáció elörehaladtával a nagyvárosok jellegét és jelentőségét milyen tényezók alakítják, és ezek ismeretében kísérletet teszünk a nagyvárosok térségi jelentőség szerinti kategorizálására.

\section{Nagyvárosi fejlödés a globalizálódó térben, az új évezred küszöbén}

A gazdaság „nemzetköziesedésével,” az országok, népcsoportok közötti, a komparatív elönyöket értékesítő bizonyos mértékü területi munkamegosztással a civilizált világban ugyan már az ókorban megkezdődött, de földi méreteket csak az Újvilág felfedezése után öltött a nemzetközi kereskedelem. A némi egyszerúsítéssel az internacionalizálódás magas fokának tekinthető globalizáció a nagyvárosfejlődés különleges fontosságú tényezöje.

\section{Globalizáció/polarizáció - regionalizáció}

Korunk kardinális jelenségei között a globalizáció sem kivétel abban a tekintetben, hogy meghatározásának zavart okozóan sok változata ismert a politikai/gazdasági/ideológiai és más érdekek által motivált probléma megközelítési lehetőségeinek változatossága okán.

Így a globalizálódás elméleti értelmezöi körében a többség a világ gazdasági, kulturális, sỏt politikai egységesülését és expanzióját tartja lényegesnek. Ebbe bele tartozik a nemzetköziesedés folyamatának az egész Földre való kiterjedése, tehát a glóbus gazdaságának horizontális kitágulásával a világgazdaság szerves rendszerré formálódásának megállíthatatlan, az igények és azok kielégítési módjának uniformizálódásával a nemzetállam végét jelentő történelmi folyamat, ezáltal az országok között kialakuló kölcsönös függỏség, illetve a világgazdaság szereplői közötti interdependenciák intenzivebbé válásával a nemzetköziesedési folyamatok vertikális dimenziójának felerósödése, azaz a transznacionalizálódás. Mindezek következményeként a gazdasági/társadalmi/kulturális rendszerek földrajzi korlátai háttérbe szorulnak (Bayer 2002). A globalizációs folyamat gazdasági dimenziója a 
planetáris méretü (mindenekelött a pénz/töke piacon végbemenö) összefonódásban, világméretekben kibontakozó univerzálódásában mutatkozik meg, míg szellemi dimenziója a planetáris tudatban, globális ideológiában. Politikai téren a globalizmus eszméje azt sugallja, hogy a nacionalizmus elavult (Csikós-Nagy 2002).

Kisebbségben vannak azok, akik a globalizációt ennél összetettebb jelenségnek látják, és egymással (látszólag) ellentmondásos folyamatok (mondializáció fragmentáció, integráció - dezintegráció, globalizáció - regionalizáció stb.) egyidejüségére hívják fel a figyelmet, és az integráció szándékával frappáns új szórövidítésekkel sürítik össze egyetlen szóba (glokalizáció, fragmegráció) a két oldalt (Vitányi 2002).

Ugyancsak megoszlanak a vélemények a globalizáció múltjáról és a fö akcióterïleteiről. A gazdaságtörténet iránt fogékony közgazdászok a mai globalizációban csupán az országhatárokat átlépő (gazdasági) nemzetköziesedési folyamatok magasabb szintjét látják. „A globalizáció ... igen régi, még ha fogalma új is” (Bayer 2002). Ezen az alapon véleményem szerint a globalizáció akár évezredekkel is „visszadátumozható." Ilyen megfontolásból Chicán (2002) utal arra, hogy a kultúra és a sport (az olimpiai játékok - E.F.) globalizációja régebben kezdődött, mint a gazdaságé, de a tudomány globalizálódása sem mai keletű. A nemzetközi gazdaságon belül legmélyebbre hatóan a pénzügyi szférában ment végbe a globalizáció miután a pénzt gyakorlatilag a korlátlan mozgás jellemzi. E tulajdonság egyben magyarázatul szolgál arra a tapasztalati tényre, hogy a reálszféra miért marad el a globalizálódás mértékében a pénzügyi szféra mögött, annak ellenére, hogy a logisztika imponáló fejlődése és mai teljesítménye hathatósan támogatni képes a reálszféra globalizálódását (Chicán 2002).

A globalizációval foglalkozók közül még azok is, akik erősen „visszalapoznak” a történelemben, elismerik, hogy a minőségében újszerü, felgyorsult globalizáció (mint az emberiség történetének új szakasza) igazán a 20. sz. közepétöl/utolsó harmadától kezdődött el.

A gazdasági globalizáció fő folyamatainak Thrift (1994) a pénzügyek globalizációját (a pénzvilágnak a termelés feletti hatalmát), a termelés globalizációját és a globális oligopoliszok folyamatos erósödését, az ismeretek (tudás) globalizálódását és a tudásstruktúrák, valamint a szakértő rendszerek fontosságának növekedését, a transznacionális üzleti szektor növekedését (beleértve a transznacionális gazdasági diplomácia erősödését) és az állami hatalom növekedését tartja.

A globalizáció a szellemi/gazdasági erőforrásokat kivételes helyeken összpontosítva világméretü polarizációhoz vezet.

Csikós-Nagy $(2002,25)$ a datálást illetöen meglepö látásmódja szerint ,,a gazdaság reálszférájában a 18-19. sz.-ban egyértelmúen a globalizáció, a 20-21. sz.-ban viszont inkább a polarizáció a meghatározó" a társadalmi-gazdasági fejlödés fö irányzata tekintetében. Jelentőségben a polarizáció (,kemény” jelenségként) felüimúlja a kiegyenlítő irányzatot (mint "puha" jelenséget). E folyamatok közepette a térségi kapcsolatokat nem a földrajzi közelség, hanem a problémák hasonlósága, a közös vallási és kulturális gyökerek, azonos érdekek alakítják, nem kormányok, hanem transznacionális szervezetek formálják. 
A távoli térségek közötti kapcsolatokat kibontakoztató, a távjelenlét lehetôségét kihasználó globalizálódás szabályozó tényezője a piaci preferencia. Ezzel szemben a szomszédos országok/térségek közötti (nemzetközi szerzödésekkel kodifikált) együttmúködéseken, kapcsolati rendszereken alapuló nemzetközi regionális kapcsolatokban megtestesülő regionalizálódás szabályozó tényezője a politikai preferencia. Az országok meghatározott csoportja ez esetben az összes többi országgal szemben a megkülönböztetés politikáját alkalmazza. A globalizációval járó polarizálódással szemben a regionalizmus térbeli harmonizációra, a kiegyensúlyozottabb állapot megteremtésére is irányuló rendszer. (Az EU mint az „európaizálódás” letéteményese a nemzetgazdaságok közötti interdependenciák erősítését segíti elö.)

Az országhatárok után már a földrészek határain is átlépő, egyre sokasodó és erősödö funkcionális kapcsolatok, összefonódások eredményeként a nagyvárosok az egymással versenyben álló központok világméretủ rendszere elemeiként értelmezhetök (Friedmann 1995). E jelenség is hozzájárult ahhoz, hogy a globalizáció és a városfejlödés közötti komplex kapcsolat a városhálózat kutatás egyik izgalmas témájává vált.

\section{A multi/transznacionalista vállalatok mint a gazdaság globalizálódásának meghatározó tényezői}

A globalizációs folyamatok fö gerjesztői, meghatározó erői és élvezői az 1950-es évektől kialakult globális multinacionális óriásvállalatok, amelyek a termelés nemzeti határokon átnyúló, a munkafolyamat egyes fázisainak egymástól távoli országokban való megszervezésével mondiális jelenséggé válva behálózzák az egész Földet. Méretükre találóan utal Toffler (2001): „Valamikor a nagy birodalmakról mondták, hogy bennük sohasem nyugszik le a nap. Ma ez a mondás a legtöbb kontinensen jelenlevö multikra érvényes." (Ugyan több tízezer olyan vállalat létezik, amelyeknek saját országukon kívül is vannak fiókintézményei - közülük az egyötödnek legalább 6 országban -, azonban ezek közül csupán néhányszáz a világot átfogó, globális tôkekonglomerátumoknak a száma, amelyek uralják a világgazdaságot.) Hatásuk ellentmondásos (jelen cikkben nem részletezendő) folyamatokban manifesztálódik:

- világméretü polarizáció az általuk előidézett koncentrációs folyamatok következtében (tőke, trendalakítás, médiahatalom tekintetében),

- kiegyenlítö irányzatok (árukínálat/-választék, civilizációs és életviteli minták, divat, fogyasztói szokások stb. tekintetében), amely folyamat az egész világot uraló gazdasági hatalom megoszlásához, policentrikussá válásához vezet.

Abból adóan, hogy a világ legtöbb multinacionális vállalata az Egyesült Államokban jött létre, és tőkéjükben is felülreprezentált az amerikai jelenlét, valamint tényként kezelve a multiknak az USA állami vezetésére gyakorolt erős befolyását, egyesek az egész világ gazdaságát irányító „globális kormány” mindenhatóságát feltételezik. Ezzel szemben a mérsékeltebb nézetet valló Toffler (2001) által a hozzávetölegesen az ipari társadalommal szinkron „,második hullámot” követö, már erősen az 
információs gazdaság és társadalom által meghatározott „harmadik hullám”-ról írt vízió tulajdonképpen a hálózatok/matrixok diadalának apoteózisa.

A nemzeti jellegüket már régen elveszítő multinacionális tőkekonglomerátumok mint a globális piac szereplői számára mind az igényelt szolgáltatások nagyságrendje és minősége szempontjából, mind logisztikai hálózatépítésük követelményei, mind a tágabb értelemben vett termelési tényezők és piaci szegmensek térben összpontosított rendelkezésre állása szempontjából a metropoliszok, illetve metropoliszrégiók képesek megfelelö léptékü telephelynek és akciótérségnek bizonyulni.

A multinacionális óriáskonszernek és pénzintézetek szerepét a nagyvárosok életében általában pozitívnak ítélik a városok jövedelmi viszonyai, a helyi adóképzés szempontjából és a sokféle címen elöálló bevételek alapján. Azonban a megítélés szempontrendszerének tágításával más végeredményhez jutnak a monográfikus vizsgálatok. Kiderülhet, hogy a multik - minden lépésüket a kizárólag a méretgazdasági megfontolásból megítélt termelékenységi szempontnak alárendelve - általában érzéketlenek a nagyvárosokban nem kis mértékben általuk keltett szociális/társadalmi és környezeti problémák iránt. Éppen a metropoliszrégiók demonstrálják a legvilágosabban, hogy mennyire nagy a különbség a szük vállalati (gazdasági) érdekek alapján értelmezett termelékenység és az össztârsadalmi aspektusú, tág értelemben vett hatékonyság között. E felismerés alapján pedig megkérdőjelezhető a metropoliszokra mint növekedési/fejlesztési központokra alapozott fejlesztések helyessége. Így pl. Németországban, ahol a német metropoliszrégiók fejlesztési koncepciója a policentrikus területfejlesztés/rendezés már régen megfogalmazott, térszerkezeti eszményképét is szolgálja a versenyképesség javítása mellett. A német területrendezés a metropoliszokban való gondolkodást a globalizációs folyamatnak a fenntartható regionális fejlődés érdekében való „megnyergelésének” szándékával, továbbá a funkció megosztásukból és hálózatosodásukból adódó előnyök kihasználására való törekvéssel indokolja (Michel 1998).

\section{A világvárosok mibenlétét meghatározó és hierarchiáját alakítani képes föbb tényezók}

\section{Mitól világváros egy nagyváros? - A világváros mint intuitív fogalom}

Minden fogalomalkotás csak meghatározott szempontok érvényesítésével, a valóság egy részének meghatározásával, durva általánosításokkal és egyúttal számos szempont elhanyagolásával történik. E probléma természetesen az olyan - különféle oldalakat átfogó - fogalmak kialakításakor és használatakor is elbizonytalanító, mint a világváros vagy a globális város.

A világváros a településtudományi, -tervezési, közgazdasági, földrajzi és más szakpublicisztikában, méginkább a zsurnalisztikában igazából egy „gumifogalom”, meglehetösen szubjektív - jobbára az intuicióra, tehát nem éppen megbízható tényezöre alapozott - megítéléssel „odaítélt" rang, illetve egyes nagyvárosok kiemelésére, megkülönböztetésére meglehetősen önkényesen alkalmazott jelzőszerủ megnevezés. 
Annyi bizonyos, hogy attól, hogy egy nagyváros „világvárosi fényben úszik”, hogy lakóit és látogatóit szemkápráztató látványok, a tágabb értelemben vett ,kirakatok", az épületek és a szédítő forgalom, az emberáradat nyüzsgése kápráztatják el, még egyáltalán nem biztos, hogy az ilyen attraktív város kiérdemli a világváros megnevezést.

Abban szinte mindenki egyetért, hogy a világváros nem elsősorban nagyságrendi, tehát alapvetően a népességszámtól függö kategória. A Harmadik Világ - akár tízmillió lakosnál is többet számoló óriásai a központjuktól eltekintve tulajdonképpen gigantikus „falvak”, primitív lakhelyek halmazai. Ezek funkcionális kisugárzása a legjobb esetben is az országhatárnál véget ér, viszont bennük a fejlett országok metropoliszainak vonzása érvényesül. Végső soron e kiszolgáltatott gigatelepülések az ,,igazi”, jóval kisebb népességủ világvárosok gazdasági vonzásterületének részei.

Vitathatatlan, hogy a világváros térfunkcionális városkategória. Olyan nagyváros, amelynek tevékenysége, interakció rendszerének kisugárzása/vonzása nemzetközi léptékủ. Tulajdonképpen pontosabb lenne a „,nemzetközi város" általános fogalom használata, mivel valójában a „világvárosok” túlnyomó része (megnevezésükkel ellentétben) nem az egész Földön, hanem annak csak egy részén képes jelen lenni különféle szerepköreinek gyakorlásával.

A témával foglalkozó eddigi (főként angolszász) szerzők a világvárosok mibenlétét, létmeghatározó tényezőit változatos - de funkcionálisan egymáshoz mégis közelálló -, túlnyomóan gazdasági kritériumok alapján határozták meg.

Hazánkban az RKK fővárosi mühelyének kutatói ugyan elsősorban Budapestnek a világvárosi hálózatban elfoglalt helyét vizsgálták, azonban ehhez nem kerülhették meg a világvárosok mibenlétének, meghatározó tényezőinek általános problematikáját, a világvárosok áttekintését sem. Így került sor a nemzetközi metodika és szempontrendszer adaptálásával, majd több új tényezővel való kiegészítésével részben Budapestnek a nemzetközi városi kontextusban, részben a közép-európai fóvárosok körében való elhelyezésére, pozíciójának a hierarchiában való kijelölésére.

Enyedi (1998) a Budapesttel összemérhető nagyságrendü két közép-európai fóváros és négy nyugat-európai nagyváros adatait hasonlította össze különféle jellemzők alapján, amelyek közül kiemelésre érdemes a tercier szektor aránya, a nemzetközi kiállítások száma, a külföldi biztosítótársaságok száma, a metróhálózat hossza és a légi közlekedésre vonatkozó föbb adatok.

A statisztikai kiadványok enyhén szólva nem kényeztetik el a világvárosok funkcióit kutatókat. A pénzvilág legtekintélyesebb lapjai (Future, Economist, Financial Times, The Banker stb.) is inkább csak országok, vagy még gyakrabban cégek/társaságok szerint közlik a különféle tőke és pénzmozgási adatokat, városi bontásban ritkán. Ezért csak a cégek telephelyének, központja hollétének ismeretében lehet megfelelö városi bontású aggregált adatokhoz jutni. Még körülményesebb a ,puha tényezők” (szellemi/kulturális kapacitások, világrendezvények stb.) számbavétele. Leginkább hiányolható azonban

- a kommunikációs (közlekedési/távközlési) infrastruktúra potenciál igényesebb, soktényezös megjelenítése, és teljesen hiányzik 
- a nagyvárosok közötti kommunikációs kapcsolatok feltárása.

$\mathrm{Az}$ adathiány miatt az eddigi munkák jobbára csak a pénzügyi jellemzők és a multinacionális cégek elemzésére összpontosítottak, és legfeljebb epitetum ornansként, vagy kiegészítésként vonták be a kommunikációt, valamint a soft tényezőket az értékelésekbe.

A világvárosok hierarchikus kategorizálása aszerint történhet, hogy Földünk mekkora részén képesek érvényesíteni funkcióikat. E kérdéskört - vagyis a regionális világvárosoktól a globális városokig terjedő kategóriák kritériumait és tagjaik ismertetését - az utolsó fejezet tartalmazza.

A következő fejezetek a világvárosok lehetséges kritériumainak kiválasztásával, és az ezekkel kapcsolatos leglényegesebb elemzések főbb eredményeinek összegzésével igyekeznek megalapozni a kategorizálást.

\section{A hatalom mint föszereplö}

A világvárosok alapvetö jellemzője a hatalom, nevezetesen, hogy bennük allokálódik a nagy területekre kiterjedő hatalom. Ezzel egyúttal a hatalom térbeli megoszlása egyenlőtlenségének is a metropoliszok a legföbb tényezői. Már Friedmann (1995) felismerte, hogy a világvárosok hierarchizálásának legmegbízhatóbb alapját a hatalmi viszonyok differenciáltsága adja. Valóban, az eddigi világváros vizsgálatok kimondva vagy kimondatlanul a hatalmat, konkrétan a gazdasági erővel korreláló gazdasági (és az ebből származtatott politikai) hatalmat állították az elemzések központjába. Elhanyagolták viszont a világvárosok más, „puha” funkcióinak vizsgálatát. Pedig a vallási központok egyúttal igen nagy területeken érvényesülö hatalmi központok is. Igaz, hogy Róma kivételével a többi (pl. Jeruzsálem, Mekka) nagyságát tekintve nem metropolisz. Az ipari termelés, vagy kiterjedt vonzáskörzet lakosságának nyújtott kiskereskedelmi szolgáltatás sem igazán figyelmet édemlő nagyvárosi funkció, de bevonásuk az értékelésbe a hatalom gyakorlás szempontjából is elhanyagolható.

Milyen tulajdonságai által és milyen megnyilvánulási formációkban, dimenziókban, szerepkörökben képes a hatalom a világvárosok attribútumává válni? Számos változatban fogalmazódtak meg a kérdéssel kapcsolatos hatalom felfogások:

- Friedmann (1995) szerint a mindenekfölött álló hatalom az erőforrások gyökerének, míg

- Allen (1994) véleménye alapján kapacitásának köszönhető.

- Sassen (1994) szerint a világvárosok a gazdasági globalizáció egymással versengó stratégiai helyei, azaz centrumai.

Castells (1994) viszont az áramláselméletébe illeszkedỏen a nagyvárosokat az „áramlások állomásának" tekinti. Szójátékkal érzékeltetve a kétféle felfogást a városok és hálózatok viszonyáról, az az elméleti (megválaszolatlan) kérdés merül fel, hogy városhálózatokról van-e szó (amikor a városok alkotnak hálózatot), vagy a városok hálózatáról (amely esetben a hálózat hozza létre a városokat. 
Mivel a téma szempontjából a hatalomnak az az oldala, hogy összekapcsol, fontosabb annál, hogy (hierarchiában) a többiek felett áll, Taylor (2000) úgy látja, hogy a hatalomnak a világvárosokban való összpontosulása inkább hálózatos, mintsem hierarchikus természetü. A hatalom hálózatosan szétterül és konkrétan a csomópontokhoz kötödik.

Taylor a különféle megközelítéseket egyesítve a világvárosokat globális hatáskörủ szolgáltató rendszereknek, illetve állományukat összekapcsolódó hálózatoknak tekinti. A világvárosnak nem az a lényege, hogy fizikailag mi minden koncentrálódott benne (épületekben, vállalati központok számában, tỏkében stb.), hanem hogy mekkora hálózatot müködtet a világ számos részére telepített alközpontok, kirendeltségek, valamint az ügyfelek révén.

\section{A multinacionális óriásvállalatok és pénzintézetek, valamint a tőzsdék szerepe a világvárossá válásban}

A globalizáció meghatározó erői, a nemzeti jellegüket már régen elveszítő, a világot átfogó multinacionális tökekonglomerátumok mint a globális piac szereplöi számára, mind az igényelt szolgáltatások nagyságrendje és minősége szempontjából mind az egész világpiac időveszteség nélküli elérhetőségét, irányítását lehetővé tevö legkorszerübb és nagy teljesítményü logisztikai/kommunikációs (közlekedési és telematikai), továbbá pénztechnikai hálózatépítésük követelményei, mind a tágabb értelemben vett termelési tényezők és piaci szegmensek térben összpontosított rendelkezésre állása szempontjából a metropoliszok, illetve metropoliszrégiók képesek megfelelö léptékü telephelynek és akciótérségnek bizonyulni.

A multinacionális tőkemenedzsment vonzódása a nagyvárosokhoz (az economies of scale érvényesülése folytán) már a 20. sz. elejétöl észlelt jelenség, amelynek következtében ma jól felismerhetö az irányító funkcióknak a világ egy vagy nagy részére kiterjedỏ pénzügyek, szolgáltatások összpontosulása.

A szükített értelemben vett gazdasági megközelítésben a világvárosok értékelését a multinacionális (ipari, termelöi infrastruktúra üzemeltető) vállalatközpontok allokációja, valamint a pénzvilágban betöltött szerepe (pénzintézetek száma, tőkemenynyiség) alapján végezték el (Castells 1994; Smith-Timberlake 1995).

A multinacionális óriásvállalatok központjainak jelenléte, gyakorisága a világvárosokban

Miközben az ipari termelés hozzájárulása a világvárosok értéktermeléséhez folyamatosan csökkenö irányzatú (mivel a gyárakat részben a saját országon belüli vidéki térségekbe, méginkább az olcsó termelési feltételeket nyújtó fejletlen országokba telepítik át), a nemzetköziesedett, nagy számú külföldi telephellyel rendelkező ipari mamutvállalatok irányító (és túlnyomóan fejlesztő) központjai a legjelentösebb metropoliszokban összpontosulnak. 
E téren a földrajzi átstrukturálódás, a súlypontok áthelyezödése a távol-keleti metropoliszokba az utóbbi évtizedekben még látványosabban ment végbe mint a mamutbankok világában.

1960-ban (a fordista ipari termelés időszakában) az amerikai városok testesitették meg a nagyipar hatalmát: a világ 100 legnagyobb iparvállalatából 79 az USA városaiban müködött, közülük 29 New Yorkban, 18 Pittsburgban, 6 Chicagóban és 4 Detroitban. 1995-re részarányuk a struktúraváltás, a tercializálódás következtében az egynegyedére zsugorodott, miközben Tokió szinte a nulláról indulva kiugróan vezetö helyet volt képes elfoglalni a speciális hierarchiában: 17 központtal, azaz annyival, ahánnyal New York (6), London (5), Párizs (3) és München (3) összesen rendelkezett! A többi amerikai nagyváros közül Chicago és Los Angeles ebbéli pozíciója gyengült (6-ról 4-re, illetve 3-ról 1-re), míg San Franciscóé javult (1-röl 3-ra). A Koreai Köztársaság viharos gyorsaságú iparosításának köszönhetöen a korábban ,nem jegyzett” Szöul felkapaszkodott az elökelö 5/6. helyre, és a hagyományos nagyipari központtal, Oszakával azonos szintet foglalt el 1995-ben - amint az Short-Kim-Kuus-Wells (1996) adataiból megállapítható, illetve kiszámítható.

A világvárosok elöbbi szempontú sorrendjének megállapitásához a forgalmi értékek kifejezöerejét lényegesen jobbnak, reálisabbnak tartom, mint a vállalatok számát. A világ 500 legnagyobb ipari vállalatát tartalmazó forrás, a jó nevủ The Banker folyóirat adatsorának hibamentességében viszont azért vagyok kénytelen kételkedni, mert az első 200 között nem tartalmaz olyan - a Short-féle listán még elökelö helyen szereplö - kiemelkedő nagyvárosokat, mint Chicago, Los Angeles (mindössze 25,2, illetve 14,5 Mrd USD forgalmuk okán). Kétségtelen azonban, hogy még az alapvetően a termékkibocsátás értékét tükröző forgalmi adatok is messze nem hézagmentesen, hanem csak hozzávetölegesen indikátorai a világvárosoknak. A megavállalatok tekintélyes részének ugyanis viszonylag kis városokban müködik a központja, részben azért, mert az eredeti „vidéki” kis/középvállalatból fejlödött naggyá, és a hagyománytisztelet, lokálpatriotizmus okán ma is ragaszkodik az alapítás színhelyéhez, másrészt pedig valamilyen erős motiváció (a nagy mértékủ helyi és más adókedvezmény, a mennyiségében kevés, de kvalifikált munkaerő iránti igény, az image-javító, kellemes környezet, az olcsó ingatlan stb.) ösztönözte az alapítókat és a mai üzemeltetöket. Egyre több esetben a megavállalatoknak csak az irányító központja (esetleg tervező és adminisztratív részlege) müködik kisebb városokban, míg a termelésböl csak a végtermékgyártás (vagy még az sem) folyik a vállalati központ városában.

Így tartozik a világ elsỏ 24 - egyenként 100 Mrd USD-nál nagyobb forgalmú óriásvállalatát koncentráló városa közé pl. a 400 ezer lakost számláló amerikai Charlotte a Duke Energy és a First Union Corporation által, söt a franciaországi kisváros, a 30 ezres lakosságú Courbevoise is a Total Fina Elf olajcég jóvoltából. A 25-35. helyezettek közül Wolfsburg életét a Volkswagen Művek, az amerikai Troy-ét a Delphi Automotive és a Kmart, az ugyancsak amerikai Palo Alto-ét a HawlettPackard és a Sun Microsystems cég székhelye határozza meg. Természetesen akár lényegesen is eltérhet a városok iparvállalati bevétele alapján felállított sorrend, ha valamennyi vállalat (kisvállalatokat is beleértve) belekerült volna az adatbázisba. 
Tér és Társadalom, 17. 2003. 3. 1-27. p.

Témánk szempontjából azonban nem szabad eltéveszteni a fö célt, azaz az óriásvállalatok szerepét a világvárosi rangban.

Ugyan minden városra kiszámítottam a nagyvállalatok átlagos forgalmát is, azonban e mutatót, tehát a vállalati struktúra jellegét nem találtam olyan differencia specifikának, amely alapján fontos következtetéseket lehet tenni a világvárosi mivoltra, pl. olyan megfontolásból, hogy az ,igazi” világváros a legnagyobb vállalatok székhelye. Az első tíz világvárosban levö nagy számú vállalat átlagos forgalmi összege elmarad a 11-20. helyezett városokétól: az utóbbiakban ugyan jóval kevesebb a nagyvállalat, de ezek egyenként átlagosan nagyobb méretüek. Pl. Detroitban mindössze egyetlen vállalat, a General Motors tartozik a világ 200 legnagyobb vállalata közé, azonban ez a világ harmadik legnagyobb (180 Mrd USD-t meghaladó) forgalmú vállalata.

A texasi kisváros, Irving buiszkélkedhet a világ legnagyobb forgalmú ipari társasága, az Exxon Mobile, az ugyancsak jelentéktelen arkansasi Bentonville pedig a második legnagyobb, Wal-Mast Stores nevü (210,4, illetve 193,3 Mrd USD forgalmat bonyolító) vállalatának központjával!

A világvárosok pénzügyi központ szerepköre - a fö pénzintézeti központok

Az egész világra kiterjedő pénzügyi integrációt mindenki a globalizáció fontos vonásának tekinti. A telekommunikációs technológia forradalmától kísérten a fỏ tökepiacoknak az 1980-as évekbeni deregulációja és liberalizációja, de az internáliák és externáliák számbavétele is meggyorsította a pénz és a pénztöke transznacionális mobilizációját (Corbridge 1996). A tőkemozgások tanulmányozásakor kiderült, hogy a multinacionális pénzügyi rendszer nem követi a földrajzi logikát, azaz a földrajzi megközelítésủ települési filozófia anakronisztikussá, de még a legjobb esetben is jelentéktelenné vált a pénzügyi világban. (Szerencse, hogy a ,földrajz vége" jelszó megmaradt a pénzügyi szektor berkeiben, nem okozott pánikot a geográfiában.) Ugyanakkor nyilvánvalóbbá vált a globális pénzügyi központok számára a nagyvárosi szociális és kulturális struktúrák, továbbá a pénzcsoportok közötti verseny fokozott jelentösége (Pryke-Lee 1995).

A multinacionális ipari termelö és szolgáltató vállalatokon kívül a több, vagy sok országra kiterjedő nemzetközi pénzintézeti (itt: banki) tevékenység is lényeges attribútuma a világvárosoknak. Ennek az összetevőnek a vizsgálata korábban ugyancsak a cégek (értsd: a bankok) száma alapján történt.

Short-Kim-Kuus-Wells (1996) táblázatából kitünik, hogy a világ 100 legnagyobb bankjának a nagyvárosok közötti megoszlásában izgalmas átrendezódések mentek végbe az 1960-as évek végétöl az 1990-es évek derekáig, egyfelöl Tokió, még inkább Párizs és némileg Frankfurt javára, másfelöl New York határozott és London, Madrid, Düsseldorf némi kárára, miközben Oszaka, München, Milánó, Toronto, Montreal, Amszterdam, Róma, Zürich pozíciója lényegében változatlan maradt.

Az átrendeződési folyamat eredményeképpen 1995-ben a legtöbb (16) óriásbank központtal Tokió rendelkezett, Párizs követte a második helyen (11), Frankfurt viszont (6) megelỏzte New Yorkot (5) és az azonos koncentrációjú Londont (5). Az 
5-7. helyezett Oszakára, Brüsszelre és Pekingre pedig a bankok azonos (4-4-4) méretü összpontosulása volt jellemző. Meglepö, hogy (Short kimutatása alapján) a más tekintetben rendkívül dinamikus világváros karakterü amerikai metropoliszokban (Chicago, Atlanta, Boston, Philadelphia, Dallas) egyetlen megabank sem volt 1995-ben, ahogyan más földrészek olyan tekintélyes városaiban sem, mint Koppenhága, Rio de Janeiro, Sydney, Hongkong, Sao Paulo, Bécs, Szöul stb.), és csupán egyetlen egy megabank központot mondhatott magáénak, pl. Berlin, Torino, Düsseldorf, Melbourne, San Francisco. Amennyiben szükebb kört vizsgálunk és csupán a világ 20 bankóriását vesszük alapul, Tokio (8), Párizs (4) és Oszaka (2) szerepe (a hányadok alapján) még kiugróbb volt.

$\mathrm{Az}$ ipari/szolgáltató megavállalatok megoszlás vizsgálatához hasonlóan a nagy bankok szerepének részletesebb és aktuálisabb vizsgálatakor nem a cégek (az adott városban székelö óriásbankok) számát, hanem tőkéjük különbözö mutatókkal kifejezhetỏ nagyságát vettem alapul.

- Az óriásbankok tökeereje (Strength Tier One Capital) alapján 2000-ben Tokió hatalmas elönnyel vezet, egymaga olyan nagyságot képvisel, mint az utána következő London és Párizs együttvéve. Figyelemre méltó, hogy milyen közeliek London, Párizs és New York értékei. Peking a gyakorlatilag már a kvázi piacgazdaság kibontakozását lehetővé tevő gazdaságpolitikának, és a „kiszolgált” Kína birodalmi méretének köszönhetöen az 5. helyre emelkedett fel. (A szerző 2002, októberi látogatásakor autentikus szakemberek 2010-re Peking 3. helyét helyezték kilátásba.) Osaka 2000-ben lényegesen megelőzte az utána következő „második vonalbeli” négy (milliósnál kisebb) európai pénzügyi központot (Frankfurtot, Zürichet, Amszterdamot, Brüszszelt). A 11-20. helyezettek közül csak kettó európai (a nagyváros Milánó és a középváros Bilbao), míg a többi észak-amerikai, távol-keleti. Egy város képviseli Ausztráliát is. A 21-35. helyet elfoglalók közül 11 európai, 3 északamerikai, egy ausztráliai.

Kizárólag az óriásbankok körére abból a megfontolásból szorítkoznak a számítások és értékelések, hogy ezeknek van esélyük a nemzetközi, vagy éppen a Föld nagy részére kiterjedö pénzpiacon való aktív részvételre. Meg kell azonban jegyeznünk, hogy egy város a tényleges összes tỏkeereje alapján lényegesen más pozíciót foglalhat el az elöbbihez képest. Pl. a több millió fönyi népességủ Madrid a mindössze 5,7 Mrd USD tőkével nem jutott be az első 35 közé (miközben a hatodakkora Bilbao a 20., Santander a 24.), mert jó néhány - de egyenként viszonylag kis - bank központjának ad helyet, amelyek együttes tőkéje viszont akkora összeget tesz ki, amelynek alapján megelőz néhány 35-ön belüli várost (pl. Helsinkit, Dublint).

- Mintegy további variációként szerepeltettem a városok eszközérték alapú (Size Assets) rangsorolását is, amely - az óriásbankok eltérő gazdálkodásának, üzletpolitikájának következtében - nem elhanyagolható mértékben különbözik a tőkeerő alapú sorrendtől, különösen az alacsonyabb (11-20., méginkább a 21-35.) sorrendállományban. E mutató alapján nem kerültek be 
a „harmincötök” közé olyan, a köztudatban a jelentős bankvárosok között nyilvántartott több milliós, rendkívül fejlett nagyvárosok, mint Szingapur és Chicago (a 131 Mrd, illetve 110 Mrd USD saját banki eszközállománnyal).

\section{A tözsdék és börzék különleges jelentösége}

A részvények és kötvények mennyisége, illetve a részvényforgalom is alapul szolgálhat a világvárosok sorrendjének megállapításához.

A tözsdéjükön bejegyzett vállalatok száma alapján a „Hármak” előnye ugyancsak egyértelmü. (E körön belül a belföldi cégek számát tekintve New York, a külföldiek száma alapján London a világelső.) A tőzsdék nemzetközi jellegét meghatározó külföldi cégek száma alapján Frankfurt, Párizs, Zürich és Amszterdam is megelözi New Yorkot és Tokiót. Tokió „globalizáltsági” foka ugyan a kulturális/nyelvi sajátosságok okán minden tekintetben kétségtelenül kevésbé intenzív, azonban szó sincs arról - ahogyan azt egyes szerzök beállítják -, hogy a külföldi tókejelenlét minimális lenne. Az kétségtelen, hogy Tokió tỏkekihelyezése jóval nagyobb, mint az idegen töke felvétele. (Pl. az USA-ban müködö 50 legnagyobb külföldi bankból 14-nek a központja Tokióban van.)

A „Hármak” elönye a pénzvilágban igazán markánsan a tőzsdék értékpapir forgalmának méretében mutatkozik meg. E tekintetben New York fölényesen az elsö, Tokió a második, és London a harmadik helyet foglalja el. Az utánuk következö 4-11. helyezett közül öt (Párizs, Frankfurt, Zürich, Amszterdam, Miláno) európai kettő kivételével még csak nem is milliós nagyváros.

A börzeforgalom alapján New York ugyancsak az első a metropoliszok közül (1. táblázat). Ugyanakkor London kiváló pozícióját (2. helyét) minősíti, hogy ott összpontosul nemcsak a globális devizakereskedelem egyharmada, hanem a börzekereskedelemben is a frankfurti üzleteknek mintegy háromszorosa bonyolódik a Temze partján.

\section{TÁBLÁZAT}

A börzekereskedelem méretei a vezetö három világvárosban 2001 szeptemberében (The Extents of the Stock Exchange Trade in the Leading Three Metropolis in Sept 2001)

\begin{tabular}{lcccc}
\hline \multirow{2}{*}{\multicolumn{1}{c}{ Tételek }} & Frankfurt & \multicolumn{2}{c}{ London } & \multicolumn{2}{c}{ New York } \\
\cline { 2 - 5 } & $\begin{array}{c}\text { Német } \\
\text { Börze Rt. }\end{array}$ & $\begin{array}{c}\text { London Stock } \\
\text { exchange }\end{array}$ & NYSE & NASDAQ \\
\hline A börzén bejegyzett & & & & \\
részvénytársaságok* & 750 & 2450 & 1966 & 3737 \\
$\begin{array}{l}\text { Belföldiek } \\
\text { Külföldiek }\end{array}$ & 235 & 469 & 452 & 458 \\
Összesen & 985 & 2919 & 2418 & 4195 \\
\hline Belföldi részvénytársaságok & 945,8 & 2050,8 & 10138,0 & 2120,0 \\
piactökésítése (Mrd USD) & & & & \\
\hline Börzeforgalom (Mrd USD) & 1151,3 & 3550,7 & 7992,9 & 8644,0 \\
\hline
\end{tabular}

* beruházási alapok nélkül

Forrás: Die Bank. 2002/4. 226. o. 


\section{A globális gazdasági hálózatban betöltött szerep, a nagy területen érvényesülö kisugárzás}

Taylor (2000) nem hive annak, hogy a városok hatalmi erejét kizárólag a hatalom mennyiségi mértékével (vezérigazgatóságok száma, a tôzsdei forgalom, a müködő specialisták száma stb.) mérjék, és ez alapján állítsák össze a rangsortáblákat. A nagyságrend mellett, vagy némelykor akár attól függetlenül is fontosabb, hogy hogyan kapcsolódik a város a globális hálózathoz, mennyire érvényesül a kisugárzó ereje a távoli térségekben. Ilyen megfontolásból egy kisebb világvárosbeli központi iroda a Föld különböző térségeiben jelenlevő kirendeltségeivel, partnereivel fontosabb lehet a világváros hálózat formáció (de a telephelyét adó világváros) szempontjából is, mint egy olyan óriás cég, amelynek kevés a külső kapcsolata, nem fejlett a kirendeltségi/partneri hálózata. Ezért, ami valójában meghatározza a városhálózat összekapcsoltságát, az Taylor szerint nem más, mint hogy a városok hogyan kapcsolódnak az egyes cégek irodái közötti tevékenységek révén. Ezért e kapcsolatok mérésével rangsorolta a neves szerző a városokat.

Az előbbiek alapján a 316 város vizsgálatakor Taylor csak azokat a cégeket vette figyelembe a minősítéshez, amelyeknek legalább 15 városban van irodájuk, és közülük legalább egy irodájuk található a három globális gazdasági eröközpont (Észak-Amerika, Nyugat-Európa, Távol-Kelet) mindegyikében. Ezeket tekinti „globális szolgáltató cégek"-nek. Jellemző a posztindusztriális korunkra, hogy a száz minősített cég közül egy sem volt iparvállalat, hanem valamennyi a szolgáltatási szektor különbözö ágaiban tevékenykedett: 18 könyvitelben/könyvvizsgálásban, 15 reklámüzletben, 23 bank és más pénzügyi szolgáltatásban, 11 biztosításban, 16 jogi tanácsadásban és képviseletben, 17 menedzsment tanácsadásban.

A hálózathoz kapcsolódás egy város számára elönyökkel jár; minden cégének nyújt valamit. A város szolgáltatásainak értéke megsokszorozódik cégeinek minden más városban végzett szolgáltatásai, illetve azok értéke által. E „termékek” összessége meghatározza egy város cégei számára a városok hálózatával való kapcsolatot. Ezt az értéket (mérőszámot) több részletben jelentetik meg a vonatkozó írások. Annál jobb helyezést ér el a rangsorban a város, mennél több céget fogad be és azok mennél nagyobb értékủ szolgáltatásokat végeznek.

A Taylor által kidolgozott probléma megközelítés, illetve számítási módszer alapján London világelsö a legmagasabb szintü és legkiterjedtebb hálózatosodásával. Összesen 123 olyan város létezik a Földön, amelyek nemzetközi kapcsolataik egyötödnél nagyobb hányadát Londonnal építették ki. Ezek valamennyi földrészt képviselik; tehát Londonnak valamilyen mértékben minden kontinens városaival vannak összeköttetései. Legkevesebb az erősebb kapcsolatokkal rendelkező városok száma Afrikában, de az ottani 6 város területi megoszlása viszonylag kedvező minden nagyobb régióba jut belőlük. (Északon Kairó és Casablanca, nyugaton Lagos, keleten Nairobi, délen Johannesbourg és Fokváros.)

A világméretü kapcsolódásokra fókuszálva határozta meg és rangsorolta Taylor a globális hálózati kapcsolódás szintjén álló húsz várost. Ezek élén - kiemelkedő és egyúttal közelálló értékeik alapján - globális városnak London mellett csak New 
Yorkot nevezte meg (1,00 és 0,98-as értékkel). Ezek után már nagy értékkülönbséggel következik a 3. helyen Hongkong $(0,71)$. (A csoportosítás során 0,59 érték felett az első 10 város, míg a 0,48 érték felett a világ első 20 városa helyezkedik el.) A Top 20-ból 8 európai, 5 észak-amerikai és 4 ázsiai/távol-keleti város, de latinamerikai és ausztrál város is szerepel e csoportban.

Taylor vizsgálati eredményei megerösítik Friedmann (1995) jóval korábbi felismerését, amely szerint a kiemelkedö világvárosok a fejlett központi régiókon kivuül a félperifériákon is megtalálhatók, de igazolja Sassent (2000) is, aki szerint a globális városok világméretủ hálózata átvágja a régi észak-dél megosztottságot - azaz a déli féltekén is sikerült világvárossá felemelkednie néhány nagyvárosnak. (Az persze zavarja a tényleges pozíció pontos meghatározása követelményének megfelelni akaró szakembert, hogy Sassen egyszerüen globális városnak nevezi a világvárosokat, holott senki számára nem lehet vitás, hogy a világvárosok legkiemelkedöbb tagjaiból álló legfelső szint megnevezésére használtatik e szó.)

\section{TÁBLÁZAT}

A világvárosok rangsora a funkcionális összekapcsoltságuk mértéke alapján (The Order of Metropolis by the Extent of Their Functional Connectedness)

I. Globális városok: London, New York

II. A Top 10-hez tartozó többi 8 világváros: Los Angeles, Chicago, Toronto Észak-Amerikában;

Párizs és Milánó Európában;

Tokió, Hongkong és Szingapúr a Távol-Keleten.

III. A Top 20-hoz tartozó további 10 világváros: San Francisco ÉszakAmerikában;

Mexikóváros, Sao Paulo Latin-Amerikában;

Amszterdam, Brüsszel, Frankfurt, Zürich és Madrid Európában;

Tajpej és Sydney a Távol-Keleten/Pacifikumban.

IV. Más városok, amelyek többé-kevésbé világvárosi rangúak:

Panama, Caracas, Bogota, Quito, Lima, Rio de Janeiro, Santiago, Buenos Aires, Montevideo Latin-Amerikában;

Oslo, Koppenhága, Stockholm, Helsinki, Manchester, Hamburg, Berlin, Moszkva, Birmingham, Rotterdam, Düsseldorf, Prága, Varsó, Dublin, Antwerpen, Köln, Kijev, München, Bratislava, Luxemburg, Stuttgart, Bécs, Budapest, Bukarest. Lyon, Gent, Zágráb, Szófia, Barcelona, Isztambul, Lisszabon, Róma, Athén, Nicosia Európában;

Bejrut, Tel Aviv, Kuwait, Amman, Jeddah, Rijad, Abu Dhabi, Dubai a Közel-Keleten;

Casablanca, Kairo, Lagos, Nairobi, Port Louis, Johannesburg, Fokváros Afrikában;

Peking, Szöul, Shanghaj, Kanton, Manilla, Ho Shi Min város, Karachi, Bombay, Channai, Bangalore, Kuala Lumpur, Dzsakarta Ázsiában; Brisbane, Perth, Adelaide, Melbourne, Auckland, Wellington Ausztráliában és Új-Zélandon.

Forrás: Taylor 2000 alapján. 
A korábban ismertetettekkel szemben a legmeglepöbb, hogy Taylor elemzései eredményeinek tükrében (2. táblázat) Tokió - amely csupán egyetlen ismérv, nevezetesen a nemzetközi pénzügyi szerepkör alapján tekinthetö globális városnak zárkózik fel szorosan harmadikként New Yorkot követve. (A pénzügyi központ szerep értékei: London 1,00, New York 0,98 , Tokió 0,94 .)

A hálózati kapcsolatok erössége szerinti rangsorhoz képest a pénzügyi központ funkció alapján a többi világváros körében is nem elhanyagolható különbségek mutatkoznak: így pl. Frankfurt és Madrid elöbbre sorolódik, míg Los Angeles és Milánó pozíciója kedvezőtlenebb. A földrészek vonatkozásában a Távol-Kelet (7 várossal) már fölénybe került Nyugat-Európával (6 város) szemben a banki, pénzügyi szolgáltatásokban kiemelkedő világvárosok száma tekintetében. Más elemzések is arra következtetnek, hogy Kelet-Délkelet-Ázsia és Ausztrália/Óceánia vált a globalizáció ,arénájává”.

Az elöbbi táblázat utolsó nagy taglétszámú csoportjának összeállításakor a szerző rendkívül „bőkezü" volt, mivel számos olyan várost is szerepeltet, amelyek valójában a világvárosi minőség közelébe sem jönnek egy kicsit is a geográfiában tájékozott ember számára, akár mert harmadik világbeli, gazdasági szempontból igen gyenge erejü fővárosok, akár mert fejlett vagy közepesen fejlett országok csupán pár százezres lakosságszámú, a nemzetközi gazdasági porondon alig észrevehetỏ városai.

\section{A világvárosokat kiszolgáló, a nagytávolságú nemzetközi kommunikációs} kapcsolatokat hordozó rendszerek és a nagyvárosok viszonya

A világvárosok minősítéséhez megfelelö kifejező erejü kommunikációs eszközök kiválasztásakor három kizáró körülményt vettem figyelembe.

- A világvárosok általában megszabadultak egykori hagyományos termelési kapacitásuk túlnyomó részétöl, így a posztindusztriális gazdasági struktúrájú, immár az információs társadalom felé mutató társadalmi/demográfiai szerkezetük okán output-juk javarészt már szellemi termék, ezért a távolsági tömegáru szállítás alig jut szerephez a nemzetközi térben betöltött funkcionális súlyuk alakulásában.

- A világvárosok funkcionális „kisugárzását” nem befolyásolja a világléptékủ helyi közlekedés. Még a legkorszerübb és kiterjedt hálózattal rendelkezésre álló metrónak, elővárosi gyorsvasútnak is csak a település üzemelés, a településen belüli elérhetőségi viszonyok szempontjából van szerepe az eljutási lehetőség kedvezőbbé tételével. Ezért nem szerencsés a földalatti vasutat a világvárost alakító funkciók között szerepeltetni.

- A világvárosi funkciók gyakorlásával kapcsolatos személy- és részben áruszállítási feladatokra a közlekedésnek igazából csak a nagytávolsági viszonylatokban idötakarékos szolgátatásokat nyújtani képes alágazatai alkalmasak. Azonban még a nagysebességủ szupervasutak is csak néhány szárazföldi viszonylatban léteznek az ,intermetropolisz” viszonylatú személyszállításhoz. 
Tér és Társadalom, 17. 2003. 3. 1-27. p.

A légi közlekedés különleges és a tengerhajózás másodlagos szerepe a világvárosi funkciók gyakorlásában

Valamennyi közlekedési alágazat közül a légi közlekedésnek van döntö, söt többnyire meghatározó szerepe a világvárosok egymás közötti távolsági/interkontinentális nemzetközi kapcsolatának realizálásában, illetve a globális (pénz és szellemi tőke) piacon való jelenlétben.

Formálisan jó néhány mutató kínálkozik egy világváros légi közlekedésben betöltött szerepének mérésére, de legalábbis érzékeltetésére. Ilyenek lehetnek pl. a repülöterek száma, müszaki berendezettsége, forgalmi kapacitása, továbbá a teljes utasés cargo forgalma, vagy éppen a még érzékletesebbnek tủnő fajlagos (népességszámra vetített) utasszám. Az utóbbi kifejezőereje azonban témánk szempontjából nem megfelelö: a legnagyobb fajlagos forgalom ugyanis a nagyvárosok népességszám tekintetében csak harmadik (agglomerációjukkal együtt is max. 4 milliós) kategóriájába tartozó amerikai, az új tudásalapú tevékenységek kibontakozásával az utóbbi évtizedekben kiemelkedö innovatív városokra (Atlanta, Denver, Las Vegas, Dallas/Ft. Worth, Houston, Miami, Orlando, Seattle) jellemzö.

A nagyvárosok nemzetközi jelentóségének mérésére legkifejezöbb légi közlekedési méröszám - a nemzetközi légi utasok száma lehet, ami kiegészíthetỏ a nemzetközi, interkontinentális szolgáltatásokat nyújtó nagy légitársaságokra vonatkozó, súlyozáshoz szükséges adatokkal. A nemzetközi utasok száma terén a nyugat-európai nagyvárosok minden tekintetben ,aránytalanul" jó pozícióban vannak az alapjában véve belföldi közlekedésre orientált amerikai és számos más világrészbeli nagyvárosokkal szemben. Kétségtelen, hogy a 3. táblázat bizonyos összefüggést érzékeltet a nemzetközi légi közlekedés mérete és a világvárosi rang között, azonban nem kifejezetten szorosat. Azért nem, mert egyes amerikai, ausztráliai és némely távolkeleti nagy tőkeerejü városok, (amelyek egyébként multinacionális cégek müködési területei) a fizikai elérhetőségnek nem kedvező periférikus helyzetük miatt a hozzájuk közelebb eső globális városon keresztül tartják a közlekedési kapcsolatot a világpiaccal, de jobban kihasználják a telematika adta lehetőségeket is a személyes jelenléttel való „takarékoskodáshoz".

A világvárosi státus megítéléséhez ugyancsak felhasználandók az intermetropolisz jellegủ nemzetközi légi forgalom intenzitásának adatai is.

Az országhatárokat átlépö nagyvárosközi forgalomban a legutóbbi idökig Nyugat-Európa két, egymástól mindössze három és félszáz km-re fekvő globális szerepkörü városa, Párizs és London közötti forgalom vitte a pálmát a félóránál is sürübben indított ingajáratokkal kialakított valóságos „légi híddal”. A Csatomaalagút megnyitásával azonban a modern vonatokra átpártolt az utasok bö egyharmada, így a harmadik helyre csúszott vissza. Ma a Föld legtöbb tőkét összpontosító, a világkereskedelemben kiemelkedő pozíciójú globális városai, London és New York közötti forgalom áll a topon (4. táblázat). E folyosó az öt és félezer km-es távolság ellenére, maga mögé utasítja a mindössze 369 km-es Amszterdam-London viszonylatot, amely 1992 óta a 8 . helyről rukkolt elöre a 2 . helyre. A holland gazdaság imponáló teljesítményei és az innovációban élen járó brit délkeleti régiók átlag feletti gyors fejlődése, a kontinens felé ,fordulása”, valamint Amszterdam nemzetközi hub funkciójának erösödése együttesen vezettek az előre lépéshez. 
Erdősi Ferenc: Globalizáció és a világvárosok által uralt tér.

Tér és Társadalom, 17. 2003. 3. 1-27. p.
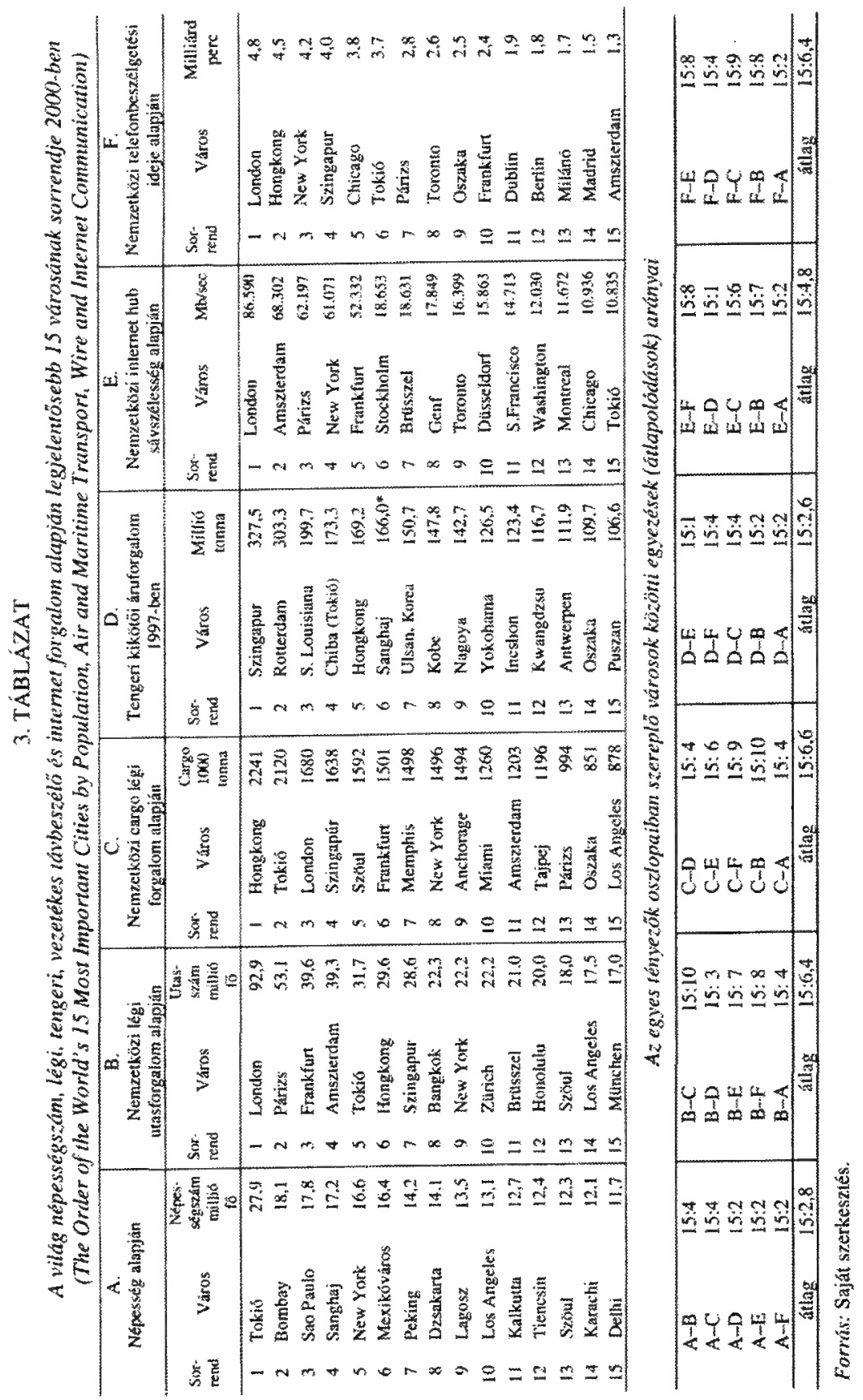
Írország a politikai függetlensége ellenére ezernyi szállal kötődik NagyBritanniához. E kötődés intenzitása pontosan lemérhető abban, hogy a tengerszoros szélességủ Ír-tengeren közlekedő komphajók ellenére a London-Dublin légi vonal az ötödik helyet foglalja el (az 1992. évi 9. hellyel szemben). Nyugat-Európa két legnagyobb gazdasági hatalmának pénzügyi/logisztikai központjait köti össze a 10. helyen levö London-Frankfurt viszonylat.

A Távol-Kelet/Délkelet-Ázsia elöretörésében (a világ legforgalmasabb 25 vonalából 14 ott múködik - 1. ábra) a gazdasági potenciál világátlagnál gyorsabb növekedése mellett két sajátos körülmény is közrejátszott a repülögép elönyben részesítésében. Az egyik, hogy a térség horizontálisan és domborzatilag is rendkívül tagolt. A másik ok etnikai: Délkelet-Ázsia több országában nagy számú kínai él. Ők a gazdasági élet legbefolyásosabb reprezentánsai, egyben a legmobilabbak.

A légi személyszállítás a globalizáció legkülönbözőbb megnyilvánulási formáinak (társadalmi, kulturális, tudományos, turisztikai globalizmus) közös hatása alatt áll, ezzel szemben a légi áruszállitás közvetlenül a gazdasági globalizációhoz kötödik. A globális gazdaság térkapcsolati rendszerének erövonalai, értékei jól tükrözödnek a fö cargo szállitó vonalak alkotta rendszerben (Erdösi 1998). A cargo szállitás legintenzívebb vonalai még a személyszállitásnál is nagyobb mértékben összpontosulnak Ázsia keleti felében (4. táblázat).

Világviszonylatban a legtöbb áru (évente mintegy 200 ezer tonna) a HongkongTokió vonalon mozog: Tokió székhelyủ japán világcégek termeltetnek a ma már Kínához tartozó egykori városállamban. Mennyiségben alig marad el ettöl egyfelöl a japán, másfelól a tajwani fỏváros, illetve az USA elsőszámú metropolisza és a Távol-Kelet „kapuja”, Szingapúr közötti áruáramlás. A világ 25 legforgalmasabb cargo légi vonalából 13 Ázsián belüli, további 8 pedig Ázsiát más földrészekkel összekötỏ vonal! Földünk ,ipari mủhelyévé” a Távol-Kelet/Délkelet-Ázsia nagyrégió vált. A cargo szállítás további, metropoliszok közötti interkontinentális irányait a legnagyobb fogyasztópiacok, Európa és Észak-Amerika határozzák meg (4. táblázat).

Mára a tengeri kikötök szerepe erösen devalválódott, miután a világvárosokra a gazdasági/társadalmi struktúrának az információs társadalom felé végbement váltásával, az anyagigényes iparok megszúnésével, illetve kitelepítésével, az értékesebb termékek légi úton való szállításával töredékére csökkent a tengeri útra utalt szállítanivaló. A hagyományos tengeri kikötők mindig is a városok ,hátsó udvarai” voltak, jobbára minden tekintetben taszító és konfliktusoktól terhelt környezetet produkálva. Ezért az utóbbi évtizedekben a városrendezési, település-rekonstrukciós müveletek, ahol lehetett, igyekeztek felszámolni, vagy - a konténeres áruszállítás és az újszerủ logisztika adta lehetőségeket kihasználva - kitelepíteni a kikötöket. E folyamat a legdrasztikusabban Londonban ment végbe.

Ma a világ 10 legnagyobb forgalmú kikötöjének csak mintegy a fele müködik valamelyik világváros közigazgatási területén. 

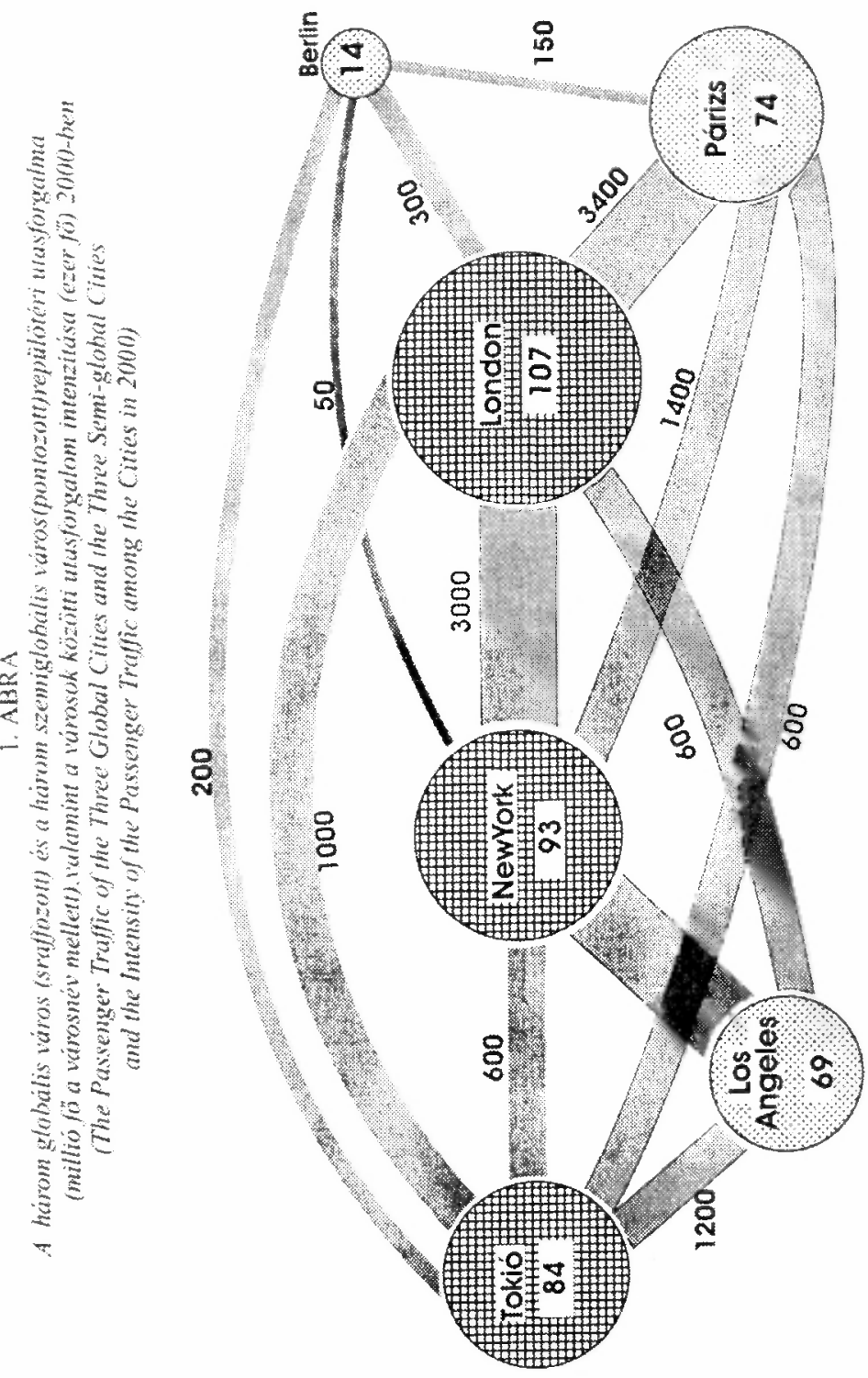

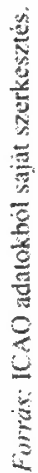


Erdősi Ferenc: Globalizáció és a világvárosok által uralt tér.

Tér és Társadalom, 17. 2003. 3. 1-27. p.

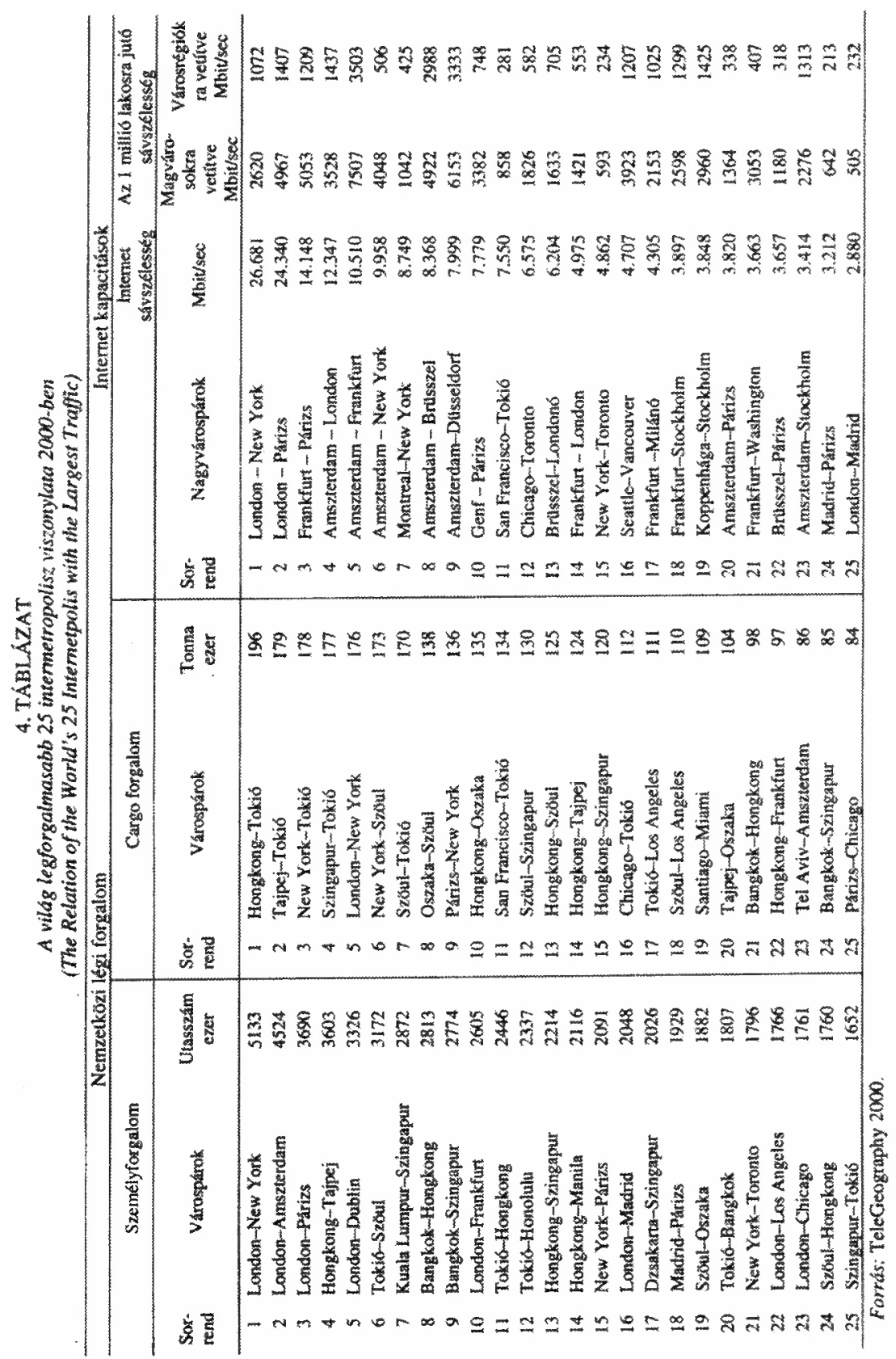




\section{A világvárosok távközlési/telematikai potenciálja és összekapcsolódása}

A gazdasági tevékenységek globalizálódásának lehetőségét, egyszersmind kényszerét a müszaki fejlődés teremti meg azzal, hogy az új technológiák kinövik az országhatárok által körülhatárolt teret. Az információs/telekommunikációs technológiai forradalom pedig egyenesen a globalizációt kiszolgáló eszközből mindinkább annak egyik kuilönös jelentőségủ hajtóerejévé válik mind a gazdasági, mind a kulturális szférában. (Utóbbiban egészen az uniformizáló „CNN-ization” jelenség általi média-kulturális kolonizációig bezáróan [Szentes 2000]).

Az információ mint erőforrás piacának robbanásszerü globalizálódása alapvetően változtatja meg a pénzügyi, logisztikai, szervezeti szféra, a munkaerópiac stb. belsö múködését. Ennek következményei egyelöre még gyakorlatilag felbecsülhetetlenek (Chicán 2002).

A még a 20. sz. elején kialakult földrészek közötti termelési, kulturális, politikai, sőt hadászati rendszerekből indulóan a telematika által nyújtott lehetőségek kihasználásával (a Föld egymástól távoli térségeiben végbemenő, viszont egymáshoz funkcionálisan szorosan kapcsolódó folyamatok egyidejü érzékelésével, befolyásolásával) az idő tényezỏ negligálódott az információáramlás tekintetében, a távolság vesztett jelentöségéböl. A világ távközlés és közlekedés általi (már Ortega figyelmét is felkeltő) „összezsugorodása” a globalizáció alapvetö „,izikai szubsztrátuma” (Ankerl 2002). Végső soron, nagy általánosságban minden kutató elismeri, hogy a világgazdaságban és a nagyvárosfejlỏdésben új stratégiai erőforrás szerepe van az információnak és a telekommunikációs rendszer kulcs infrastruktúrájának. Ezt felismerve számos nagyváros fejlesztéséhez kitüntetett szerepet szánnak az infokommunikációs technikával való „átitatódásnak”, „átszövöttségnek”. Jól hangzó programokkal igyekeznek a városok funkcionális szerkezetüket versenyképességi okokból a tudásigényes ágazatok, ezen belül az infokommunikációs szektor javára átalakítani: pl. Manchester arra törekszik, hogy Európa első „on-line városa” legyen, miközben Amszterdam „informatikai várossá”, Barcelona és Köln „telematikai”, illetve „kommunikációs várossá” alakulásában látja a jövöjét (Short-KimKuus-Wells 1996).

\section{A világvárosok által keltett globális átviteli rendszerek és távbeszélö forgalom}

A Föld legtávolabbi pontjai közötti, különösen a globalizálódó pénzvilág, a tỏzsdék által igényelt megbízható, gyors és nagyteljesítményü, müholdas átvitelre alapozott mondiális távközlés megteremtésének jellegzetes intézményei lettek az 1980-as években az ,antennafarmokkal” ellátott teleportok (Erdősi 1992). E profitorientált, általában magántőkéböl megvalósított ultramodern távközlési központok kezdetben főként a gazdasági szerkezetváltásra reagáló városrendezési múveletek során felszámolt klasszikus közlekedési létesítményekben, így tengeri kikötőkben, dokkokban, teherpályaudvarokon létesültek.

Az elsö teleport 1982-ben New Yorkban kezdte meg a müködését, Európában pedig Amszterdam volt az úttörö (1984), de a leghíresebb a londoni Docklandban épült meg. Az USA-ban 1985-ben már félszáz, 1988-ban világszerte közel száz 
mủködött (többek között Franciaországban, Németországban, Japánban, Koreában). Szaporodásuknak gátat vetett a globális távközlési átvitel technológiájában bekövetkezett átalakulás és részben az internet térhódítása.

A globális távközlés infrastruktúrájában az 1990-es évtized hihetetlen változást hozott az információ átviteli rendszerekben, miután egyértelmüen az óceánokba süllyesztett (ma már 90-100 közötti számot elérő), igen nagy (20 Gigabit/sec feletti) átbocsátóképességü újgenerációs és jóval olcsóbban üzemelö fénykábelek javára dölt el a verseny a rendkívül drága, ráadásul számos müszaki problémával terhelt, korábban tucatjával fellött müholdas átviteli rendszerekkel szemben, amelyek közül néhányat finanszírozásuk megoldatlansága miatt már megszüntettek. 2002-ben a világ tengeri fénykábel kapacitása már 77-szerese volt a müholdakénak! A kibontakozó tengeralatti információs ,szupersztráda” hálózat vonalainak parti végpontjai ugyan többségükben nem maguk a világvárosok (New York, a Tokió/Oszaka deglomeráció Sanghaj kivételével), de túlnyomó részük áttételesen azokat szolgálja, még ha müszaki okok miatt parti kisvárosokból indulnak is, vagy egészen jelentéktelen településeken érik is el a túlsó szárazföldet.

Az átviteli technológia-váltás tehát végsö soron a világvárosokat preferálja. A müholdak nem meghatározott pontokat, hanem a Föld bizonyos területeit, övezeteit szolgálják ki, sugárzásuk tehát két dimenzióban érvényesülve felületi. (Az már technológiai részletkérdés, hogy a müholdvevő központok esetenként nagyvárosokban, vagy azok közelében müködnek. Ezzel szemben a tengeri kábelek általi átvitel tulajdonképpen pontszerú, elágazásaival pedig hálózati.)

Bármennyire is sok ma már a mobiltelefon a világ fejlettebb harmadán, a nemzetközi beszélgetések mintegy négyötödét még fix telefonon bonyolították 1999-ben, de a 2003. évi elörejelzések szerint sem haladja meg a mobiltelefon aránya a 40\%-ot az országhatáron túli távbeszélgetésekböl. Ezért a fix (vezetékes) nemzetközi telefonbeszélgetések száma egyik fokméröje lehet egy nagyváros világvárosi jellegének (3. táblázat).

Világvárosok internet hub szerepben és az intermetropolisz internet forgalom

Részben a tengeralatti és szárazföldi fénykábelhálózatok adta lehetőségek okán korunk infotelekommunikációs sztárja, az egyébként központ nélküli világháló szerkezete (viszonylatainak és csatlakozási/csomópontjainak textúrája) is alapvetöen a világvárosi hálózathoz hasonul. Ami figyelemre méltó, hogy a csomópontjai (hubjai) a világgazdasági/pénzügyi központokat nem kottára pontosan képezik le, jelenítik meg, hanem bizonyos eltérések alakultak ki a két rendszer hierarchiájában.

A világ 10 legnagyobb internet csomópontja (3. táblázat) közül csupán három (London, Párizs, New York) tekinthetö igazi világvárosnak, további kettő (Amszterdam, Frankfurt) inkább csak egyetlen szerepkörben, regionális pénzügyi központként kiemelkedő, míg további két város, Brüsszel és Genf nemzetközi szervezetek (NATO, részlegesen EU, illetve UNESCO) központjaként (de meglehetösen gyenge gazdasági potenciállal) ,nagy étvágyư” információ fogyasztók. Ennél is megdöbbentőbb azonban az 1. táblázatban nem szereplő többi világváros és hub 
funkciója közötti diszkrepancia. Annak ellenére, hogy a Föld legjelentősebb multinacionális gigavállalatai közül a legtöbb Tokióban rendezte be központját, e gigaváros csupán a 17. helyen áll az internet hubok tabelláján, de a távol-keletiek közül

- még az olyan innovációs központok, mint Szöul és Oszaka is kénytelenek a 30. és 38 . hellyel beérni, és

- a nemcsak az elektronikai iparban nagy teljesítményủ, hanem a globális (tengeri konténeres, valamint légi cargo) logisztikában a gazdasági/pénzügyi tekintetben is a topon levö Hongkong és Szingapur az internet hubok rangsorában még 2000-ben is csak a 28., illetve a 33. helyen állt.

Eközben pl. Milánó a 16., Bécs a 18., Koppenhága a 20. - és ami az igazán meglepö - a világvárosok közé aligha sorolható Prága a 21., Lyon a 23., Oslo pedig a 24. hellyel büszkélkedhet (miközben pl. Budapest a 35., München a 37., Sao Paulo a 46. hellyel igencsak szerény helyezésủ).

Ugyan a világvárosok funkcionális vonzása alapvetően saját földrészükön érvényesül, viszont a legkiemelkedőbb, gyakorlatilag (munkamegosztás nélkül) az egész Földön ,jelen levö" globális városok hatalmas interkontinentális távbeszélö forgalmat bonyolítanak le. (Pl. London/Párizs és New York, Los Angeles/San Francisco-Tokió/Oszaka, New York/Los Angeles-Szingapur/Hongkong között.) A földrészekközi intermetropolisz távbeszélő forgalom szorosan korrelál a sokféle interakció által keltett világvárosok közötti kommunikációs igénnyel (a tarifabeli különbségek e tekintetben csak árnyalják az intenzitást). Ezzel szemben az intermetropolisz viszonylatú internet forgalom méretét ma még a müszaki lehetöségeken kívül emberi tényezők, a számítógépes/internet használati ismeretekbeli (,,internetaffinitási") különbségek is érzékenyen befolyásolják.

A 4. táblázat adatainak összevetéséböl és értékeléséböl arra következtethetünk, hogy

- a vezetékes távbeszéléssel ellentétben a legforgalmasabb nemzetközi internet viszonylatok közül csak három (London-New York, Amszterdam-New York, San Francisco-Tokió) földrészek közötti, a túlnyomó többsége viszont az egyes földrészeken belüli. Még a minden más kapcsolatban kardinális London-Tokió, sőt a New York-Tokió viszonylat sincs jelen a világ 100 legforgalmasabb internet összeköttetése között.

- A metropoliszközi intrakontinentális összeköttetések túlnyomó része Európában összpontosul, és némi hasonlóság fedezhető fel a légi közlekedés intenzívebb viszonylataival. Jóval ritkább az Észak-Amerikán belüli (gyakorlatilag csupán az USA és Kanada közötti), és Európához képest elhanyagolható a Távol-Keleten belüli intercity/intermetropolisz forgalom.

Annak mérésére, hogy az internet milyen intenzitással van jelen a várospárok egymás közötti kapcsolatában, a fajlagos teljesítményt (az 1 millió lakosra jutó Mbit/sec sávszélességet) ésszerủ alapul venni az értékeléshez (4. táblázat).

E tekintetben a várospárok magvárosait figyelembe véve világviszonylatban az Amszterdam-Frankfurt/Düsseldorf, Frankfurt-Párizs, London-Párizs és Amszterdam-Brüsszel viszonylatok vezetnek, és ezt követi az észak-amerikai Seattle- 
Vancouver reláció. Városrégiókra vetítve az élenjárók sorrendje: AmszterdamFrankfurt/Düsseldorf/Brüsszel/Genf, majd a Genf-Lyon, Amszterdam-London, Koppenhága-Stockholm és London-Párizs várospárok következnek.

Ilyen formán az európai internet kapcsolatokban - az előbbi adatok tükrében - a prím szerepet Amszterdam viszi, messze megelözve a sokszorta nagyobb globális városokat. Mi több: Amszterdam - világhírủ kereskedelmének, speciális tevékenységeinek (gyémántcsiszolás, ékszeripar, mükincs szakértés, biztosítás, kulturális szerepkörök) köszönhetöen - e tekintetben egyúttal világelsó is!

$A z$ internet behálózottság, illetve használat sürüsége az internet hostok és domainok számával mérhetố. Németországi vizsgálatok megrősítették azt a korábbi feltevést, hogy az elterjedés szorosan összefügg az adott város lakossága családi foglalkozási szerkezetével és képzettségének minőségével (a speciális szakmákban nagy internet igény áll elö). Érzékelhetöen növeli az intenzitást az egyedülállók (az egy fỏs háztartások) magas aránya. A másik meghatározó tényezỏ a gazdaság szerkezete. Németországban München annak köszönheti elsó helyét az élvonalbeli városok között (5. táblázat), mert magas szintủ és reprezentációjú a médiaipar (multimédia, filmgyártás) a csúcstechnológia és a tudásalapú ipar (elektronikai ipar, software stb). Mindezek következtében igen magas (48\%-os) az exporthányad a bajor föváros gazdaságában.

\section{TÁBLÁZAT}

Az internet domain nevek elterjedettsége a fajlagos intenzitás tekintetében Németország nagyvárosaiban 1999-ben (Németország átlaga mint index $=100$ )

(The Penetration of Domain Names by Specific Intensity in Germany's Cities in 1999 (Germany's Average is 100)

\begin{tabular}{lc}
\hline Város & $\begin{array}{c}\text { Viszonylagos } \\
\text { fejlettségi mutató }\end{array}$ \\
\hline 1. Munchen & 257 \\
2. Hamburg & 214 \\
3. Frankfurt & 163 \\
4. Köln & 155 \\
5. Berlin & 134 \\
\hline
\end{tabular}

Forrás: Sternberg-Krymalowski 2002.

A világvárosok jellemzö közlekedési és távközlési tényezőinek viszonya

Az 3. táblázatban szereplő 6 tényező közül a nemzetközi telefonbeszélgetések ideje, valamint a légi utas- és a cargo forgalom tekintetében élenjáró 15-15-15 városából egyezik meg a legtöbb (átlagosan 6,4,6,4 és 6,6) a többi 5 tényezó városaival, míg a legkevesebb átlapolódás ( 2,4 és 2,8$)$ a tengeri kikötői áruforgalom méretével és a városok népességszámával kapcsolatosan mutatkozik. Az internet hub intenzitásban kitünô városok közül számításaink szerint átlagosan 6,4 egyezik meg a többi öt tényezó városaival. 


\section{Következtetések}

- a világvárosi minőség, a globális folyamatokban elfoglalt pozíció tekintetében a népességszámnak nincs kifejező ereje;

- a multinacionális társaságok, globális szerepet vívő bankok számával, tőkeerövel, tőzsdei forgalommal, versenyképességgel és más elemekkel mért gazdasági-irányítási erő/hatalom mellett a posztindusztriális-mobil információs társadalom kibontakozásával fokozottabb figyelmet érdemel a világvárosokat kiszolgáló távolsági kommunikációs rendszerek vizsgálata;

- a kommunikáción belül a távolságok gyors legyozésére legjobban alkalmas légi közlekedésnek, továbbá a távbeszélö és internet hálózatokban elfoglalt pozíciónak, illetve az intermetropolisz forgalom intenzitásának van a legerösebb kifejező ereje;

- a világvárosok közötti komplex távközlési kapcsolatok mátrixának elkészítése mindaddig várat magára, amíg nem hozzáférhető́k a robbanásszerü gyorsasággal növekvő mobiltelefónia - legalább közelítỏ értékü - adatai;

- a világvárosok közötti légi forgalom mérete nagyjából a gravitációs modellel leképezhetô: hozzávetőlegesen a világvárospárok méretével, gazdasági erejével arányosan növekszik, és a távolság négyzetével fordított arányban van;

- az intermetropolisz internet, de még a fix telefon-forgalom is a gravitációs modelltől erösen eltérő szabálytalansággal alakul; a korszerü távközlés ugyan valóban képes arra, hogy összezsugoritsa („,legyőzi”) a távolságot és eljelentéktelenítse az idöt, azonban, hogy ezt konkrétan milyen viszonylatokban teszi, az nagy mértékben a már különféle (politikai/gazdasági/kulturális) tényezők által kialakult kapcsolatok erősségének függvénye. Tehát maga a kommunikáció nehezen teremt teljesen új irányú/viszonylatú jelentős kapcsolatokat.

A tanulmány elsỏ része a világvárosok mibenlétét meghatározó és hierarchiáját alakítani képes főbb „kemény” tényezők értékelését tartalmazza. A korábbi - föként a pénzintézeti/multinacionális vállalati központok jelenlétére összpontosító - vizsgálatok adósak maradtak a nagytávolságú nemzetközi kommunikációs (közlekedési/távközlési) kapcsolatokat hordozó rendszerek és a nagyvárosok közötti viszony érdemi vizsgálatával. E hiányt pótlandó a szerző részletesen elemzi a globalizálódó posztindusztriális korunkban az intermetropolisz/interkontinentális kapcsolatokban meghatározó közlekedési módok szerepét. A kiemelkedő fontosságú légi közlekedés súlyának kifejezésére a megarepülőterek utasszámánál megfelelőbb a világvárosok közötti légiutas- és cargo-forgalom mérete, mely jól kirajzolja a globális gazdaság térkapcsolati rendszerének erövonalait. (Ezzel szemben a tengerhajózás szerepe erỏsen devalválódott a metropoliszok életében.)

Az intermetropolisz-kapcsolatok, illetve -funkciók kiteljesedésében gyorsan növekszik az alkalmazott infokommunikációs technológiák szerepe. A vezetékes telefontól eltéró globális struktúrát jelenít meg az internethubok elhelyezkedése, kapacitása (pl. Amszterdam messze megelözi Tokiót, Berlint stb.). A légi közlekedéssel 
szemben a világvárosok közötti távközlési forgalom a gravitációs modelltöl erősen eltérő szabálytalansággal alakul a távolságot eljelentéktelenítő tulajdonsága miatt.

$$
\text { Jegyzet }
$$

' Jelen tanulmány két részletben kerül közlésre. A folytatás a következö számban (2003/4.) fog megjelenni.

\section{Irodalom}

Allen, A. (1994) Telecommunications and the large city-small city divide: evidence from Indiana cities. - Professional Geographer. 3. 307-316. o.

Ankerl G. (2002) A globális káosz vagy a civilizációs államok kora. - Valóság. 5. 1-26. o.

Bayer J. (2002) Globális média, globális kultúra. - Magyar Tudomány. 6. 748-761. o.

Castells, M. (1994) European Cities, the informational society, and the global economy. - New Lefi Review. 4. 18-32. o.

Chicán A. (2002) A gazdaság globalizációja és a civilizációk különbözösége. - Magyar Tudomány. 6. 730-737. 0 .

Corbridge, S. (1996) Remarking the Image of the Docklands. - Ogden, P. (ed.) London Docklands: The Challenge of Development. Cambridge Univ. Press, Cambridge.

Csikós-Nagy B. (2002) Gazdasági globalizáció. - Ezredforduló. 1. 24-28. o.

Enyedi Gy. (1998) Budapest kapuváros? MTA, Budapest.

Erdősi F. (1992) Telematika. Távközlési Könyvkiadó, Budapest.

Erdősi F. (1998) A légi közlekedés általános és regionális földrajza, légiközlekedés-politika. I. köt. Budapest, Malév Rt.

Friedmann, J. (1995) Where we Stand: a Decade of World City Research. - Knox, P.-Taylor, P.J. (eds.) World Cities in a Worldsystem. Cambridge University Press, Cambridge. 21-47. o.

Michel, D. (1998) Das Netz der europäischen Metropolregionen in Deutschland. - Raumforschung und Raumordnung. 5/6. 362-368. o.

Pryke, M.-Lee, R. (1995) Place your bets: towards an understanding of globalization, sociofinancial engineering and competition within a financial centre. - Urban Studies. 2. 329-344. o.

Sassen, S. (1994) Cities in a world economy. Fine Forge Press, Thousand Oaks, CA.

Short, I.R.-Kim, Y.-Kuus, M-Wells, H. (1996) The Dirty Little Secret of World Cities Research. Data Problems in Comparative Analysis. - International Journal of Urban and Regional Research. 3. 697-717. o.

Smith, D.A.-Timberlake, M. (1995) Conceptualising and mapping the structure of the world system's city system. - Urban Studies. 2. 287-302. o.

Sternberg, R.-Krymalowski, M. (2002) Internet Domains and the Innovativeness of Cities/Regions. European Planning Studies. 2. 251-272. o.

Szentes T. (2000) A globalizációs folyamat kedvezö és kedvezőtlen hatásai. - Magyar Tudomány. 6. 708-719. o.

Taylor, P.J. (2000) World cities and territorial states under conditions of contemporary globalization. Political Geography. 1. 5-32. o.

TeleGeography. (2000) Washington.

Thrift, N. (1994) Globalization, regulation, urbanization. The case of the Netherland. - Urban Studies. 3. 365-380. o.

Toffler A. (2001) A harmadik hullám. Információs társadalom A-tól Z-ig sorozat. Typotex Kiadó, Budapest. Vitányi 1. (2002) A civilizáció és a kultúra. - Magyar Tudomány. 6. 720-729. o. 


\section{THE SPACE RULED BY GLOBALISATION AND METROPOLISES ERDŐSI FERENC}

The study deals with the evaluation of the main "hard" factors determining and forming the existence and hierarchy of metropolises. Former studies - especially focusing on the presence of centres of financial institutions and multinational companies - was at fault for a real analysis of relation between the systems of long distance international communication connections (transportation/telecommunication) and Metropolises. This deficiency has to made up for the author analyses the role of transportation methods determining in intermetropolis/intercontinental connections in detail in our globalising postindustrial era. The extent of air passenger and cargo traffic among metropolises is rather convenient to express the weight of the outstandingly significant air transportation than the number of passengers of megaairports. It draws thoroughly the line of forces of the global economy's system of spatial connections. (Hereby the role of maritime navigation is hardly decreased for metropolises.)

The role of applied information and communication technologies quickly increases in the accomplishment of intermetropolis connections and functions. The localisation and capacity of internethubs represents a different global structure in contradiction to wire communication (e.g. Amsterdam gets ahead of Tokio or Berlin). Contrary to air transportation the telecommunication traffic among metropolises is very far from the regularity of the gravitation model due to specific characteristic, which makes the distance unimportant. 